Z. Klin. Chem. Klin. Biochem.

13. Jg. 1975 , S. $299-304$

\title{
Separation of the Coprophorphyrin Isomers I and III by Thin-Layer Chromatography
}

\author{
By Erona Schermuly and M. Doss
}

Abteilung für Klinische Biochemie am Hygiene-Institut der Philipps-Universität Marburg a. d. Lahn

(Eingegangen am 18. Oktober 1974)

Summary: An improved, specific and sensitive method for the determination of the coproporphyrin isomers I and III is described. In this method, the hydrolysis of the coproporphyrin methyl esters takes place in the silica gel layer of acid-resistant pre-coated thin-layer plates. After chromatography in the solvent system 2,6-dimethylpyridine/water (volume ratio $20 \mathrm{ml}+6 \mathrm{ml}$ ), in an ammonia atmosphere, the isomers are measured, either directly in the silica gel layer by fluorimetry, or after elution in $1.0 \mathrm{~mol} / \mathrm{l}$ hydrochloric acid. The technique makes analysis in the nanogram range possible.

The following fractions of isomer III (\%) were found in the urine of healthy subjects and patients with disorders of prophyrin metabolism $(\bar{x} \pm s ; n)$ :

\section{Controls}

Acute intermittent porphyria

Porphyria cutanea tarda
$77.5 \pm 6.4(15)$

$87.3 \pm 9.6(6)$

$67.1 \pm 11.7(16)$
Congenital erythropoietic porphyria

Erythropoietic protoporphyria

Lead poisoning
17.4

$49.2 \pm 8.7$

$95.0 \pm 4.6$

\section{Trennung der Koproporphyrin-Isomeren I und III durch Dünnschichtchromatographie}

Zusammenfassung: Es wird eine verbesserte, spezifische und empfindliche Methode zur Bestimmung der Koproporphyrin-Isomere I und III beschrieben, bei welcher unter Verwendung von säurefesten Kieselgel-Fertigplatten die Hydrolyse der Koproporphyrinmethylester in der Kieselgelschicht erfolgt. Nach Chromatographie im Lösungsmittelsystem 2,6-Lutidin-Wasser (Volumina $20 \mathrm{ml}+6 \mathrm{ml}$ ) in Ammoniakatmosphäre werden die Isomere entweder direkt-fluorometrisch (im Kieselgelchromatogramm) oder spektrophotometrisch nach Elution in 1,0 mol/1 Salzsäure gemessen. Das Verfahren erlaubt eine Analyse im Nanogramm-Bereich.

Im Urin von Gesunden und Patienten mit Porphyrinstoffwechselstörungen wurde folgender Anteildes Isomers III (\%) ermittelt: $(\bar{x} \pm s ; n)$ :
Kontrollen
$77,5 \pm 6.4(15)$
congenitale erythropoetische Porphyrie
17.4
akute intermittierende Porphyrie
$87,3 \pm 9,6(6)$
erythropoetische Protoporphyrie
$49,2 \pm 8,7(5)$
Porphyria cutanea tarda

$$
67,1 \pm 11,7(16)
$$
Bleivergiftung
$95,0 \pm 4,6(4)$.

\section{Indroduction:}

The analysis of the coproporphyrin isomers is fundamental to further progress in the study of the biosynthetic pathways of the isomer series I and III, and the pathochemistry of porphyrin metabolic disorders. It is also needed for the diagnosis of these diseases, especially the hepatic and erythropoietic porphyrias and lead poisoning.

Comparison of the literature values for the coproporphyrin composition of both normal urine (Tab. 1) and porphyric urine (Tab. 2) reveals some considerable differences in the distribution of the coproporphyrin isomers in urine.

In principle, the separation of the coproporphyrin isomers by silica gel thin-layer chromatography goes back to the work of Jensen (1), which in turn was based on the paper chromatographic method described in 1958 by Eriksen (2). A solvent system containing 2,6-dimethylpyridine was used in both techniques. Various research groups have used the Jensen method and modified indi- 
Tab. I. Coproporphyrin isomers I and III in normal urine.

\begin{tabular}{|c|c|c|c|}
\hline Author(s) & $\begin{array}{l}\text { Number of } \\
\text { subjects } \\
\text { (n) }\end{array}$ & $\begin{array}{l}\text { Amount of } \\
\text { copropor- } \\
\text { phyrin III } \\
(\%)\end{array}$ & $\begin{array}{l}\text { Reference } \\
\text { (No.) }\end{array}$ \\
\hline $\begin{array}{l}\text { Aziz, M. A. et al. } \\
\text { (1964) }\end{array}$ & $\begin{array}{l}31 \text { (Adults) } \\
9 \text { (children) }\end{array}$ & $\begin{array}{l}65 \\
81\end{array}$ & 3 \\
\hline $\begin{array}{l}\text { Koskelo. P. \& Toi- } \\
\text { lonen, I. (1966) }\end{array}$ & 18 & 77.4 & 5 \\
\hline $\begin{array}{l}\text { Koskelo, P. et al. } \\
(1967)\end{array}$ & 30 & 78.2 & 17 \\
\hline $\begin{array}{l}\text { Koskelo, P. \& Toi- } \\
\text { vonen, I. (1968) }\end{array}$ & 20 & 80 & 18 \\
\hline $\begin{array}{l}\text { Ben-Ezzer, J. et al. } \\
\text { (1971) }\end{array}$ & 62 & $71-76$ & 9 \\
\hline
\end{tabular}

(Papers from the years 1934 to 1963 , which for the most part gave no numerical indication of the isomer distribution, are not included here. Almost all the earlier authors found more of the III isomer than the I isomer.)

vidual steps of it (3-10). The small difference in the migration velocities of the two isomers limits the amount of coproporphyrin mixture which can be separated.

Other critical factors in the technique are the quality of the dimethylpyridine, the composition of the solvent system, the amount and concentration of ammonia used, the saturation of the chromatography chamber, and the method of sample preparation. These observations, together with the fact that the method for the separation of the coproporphyrin isomers was frequently varied, indicate the difficulties which are inherent in the analysis of the coproporphyrin isomers. A simplified, standardized and optimalized system for the separation of the coproporphyrin isomers has not yet been published. Since our first communication in 1967 (11), we have worked on the development of a practical method which is less troublesome and time-consuming than the original. The goal of this work is to work out a specific and precise method for the biochemical diagnostician. It should not require much equipment, should be very sensitive and give a good separation, and should be suitable for routine urine teșts. The method of hydrolyzing the coproporphyrin methyl esters in the silica gel after application to the thin-layer plate proved to be especially advantageous. In this method, the silica gel layer is thus first used as a reaction system for a chemical transformation, which is then followed by the separation of the hydrolyzed substances.

The determination is preceded by thin-layer chromatographic separation of the porphyrins according to the number of carboxyl or methylester groups in the molecule. The total amount of coproporphyrin methylester so obtained (12) is determined spectrophotometrically before the isomer analysis is carried out.

\section{Materials and Methods}

\section{Samples}

Urine samples collected over a 24-hour period from clinically healthy subjects of all ages were examined. The urine of patients with various disorders of porphyrin metabolism were also examined. They included the following:

acute intermittent porphyria, chronic hepatic porphyria, porphyria cutanea tarda, congenital ery thropoietic porphyria, ery thropoietic protoporphyria, and porphyrin elimination after oral loading with $\delta$-aminolevulinic acid.

\section{Sample preparation}

The urine samples were shielded from light and kept cool during the collection period, and were worked up according

Tab. 2. Coproporphyrin isomers I and III in the urine of patients with disorders of porphyrin metabolism

\begin{tabular}{|c|c|c|c|c|}
\hline Author(s) & Disease & $\begin{array}{l}\text { Number } \\
\text { of cases } \\
(n)\end{array}$ & $\begin{array}{l}\text { Fraction of } \\
\text { coproporphyrin III } \\
(\%)\end{array}$ & $\begin{array}{l}\text { Reference } \\
\text { (No.) }\end{array}$ \\
\hline $\begin{array}{l}\text { Chu, T. C. \& Chu, E. J.-H. (1967) } \\
\text { Chu, T. C. \& Chu, E. J.-H. (1967) } \\
\text { Chu, T. C. \& Chu, E. J.-H. (1967) } \\
\text { Chu, T. C. \& Chu, E. J.-H. (1967) } \\
\text { Chu, T. C. \& Chu, E. J.-H. (1967) } \\
\text { Chu, T. C. \& Chu, E. J.-H. (1967) } \\
\text { Dowdle, E. et al. (1970) } \\
\text { Nacht, S. et al. (1970) } \\
\text { Chu, T. C. \& Chu, E. J.-H. (1967) } \\
\text { Watson, C. J. (1936) } \\
\text { Vigliani, E. C. \& Waldenström, J. (1937) } \\
\text { Vigliani, E. C. \& Libowitsky, H. (1937) } \\
\text { Chu, T. C. \&Chu, E. J.-H. (1967) } \\
\text { Chu, T. C. \& Chu, E. J.-H. (1967) } \\
\text { Chu, T. C. \& Chu, E. J.-H. (1967) } \\
\text { Chu, T. C. \& Chu, E. J.-H. (1967) } \\
\text { Romeo, G. \& Levin, E. Y. (1969) }\end{array}$ & $\begin{array}{l}\text { Acute intermittent porphyria } \\
\text { Acute intermittent porphyria } \\
\text { Hereditary coproporphyrinuria } \\
\text { Porphyria variegata } \\
\text { Porphyria cutanea tarda } \\
\text { Porphyria cutanea tarda } \\
\text { Porphyria cutanea tarda } \\
\text { Porphyria cutanea tarda } \\
\text { Hexachlorobenzene porphyria } \\
\text { Lead poisoning } \\
\text { Lead poisoning } \\
\text { Lead poisoning } \\
\text { Lead poisoning } \\
\text { Lead poisoning } \\
\text { Congenital erythropoietic porphyria } \\
\text { Congenital erythropoietic porphyria } \\
\text { Congenital erythropoietic porphyria }\end{array}$ & $\begin{array}{r}- \\
5 \\
2 \\
2 \\
- \\
10 \\
12 \\
7 \\
4 \\
3 \\
10 \\
1 \\
- \\
2 \\
- \\
1 \\
5\end{array}$ & $\begin{array}{l}\text { III }>\text { I } \\
80-90 \\
75-85 \\
30-65 \\
\text { ca. } 65 \\
50-80 \\
\text { ca. } 50 \\
\text { ca. } 50 \\
70-75 \\
90-95 \\
\text { nearly all III } \\
\text { nearly all III } \\
\text { mostly III } \\
90-95 \\
\text { I > III } \\
15 \\
\text { much I }\end{array}$ & $\begin{array}{r}6 \\
19 \\
19 \\
19 \\
6 \\
19 \\
7 \\
20 \\
19 \\
21 \\
22 \\
23 \\
6 \\
19 \\
6 \\
19 \\
24\end{array}$ \\
\hline
\end{tabular}


to the method previously described $(12,13)$. The coproporphyrin methyl esters were eluted from the silica gel of the thinlayer plate with chloroform. After evaporation of the solvent the samples were stored at $-20^{\circ} \mathrm{C}$ until isomer analysis could be carricd out.

\section{Reagents}

Acid-resistant silica gel thin-layer plates (G 1500, Schleicher \& Scliüll, D-3354 Dassel, Krs. Einbeck).

The plates $(200 \mathrm{~mm} \times 200 \mathrm{~mm})$ were cut into strips about $70 \mathrm{~mm}$ wide with a glass cutter.

Chloroform p.a. (Merck 2445);

25\% Hy drochloric acid, p.a. (Merck 316);

Hydrochloric acid, $1 \mathrm{~mol} / \mathrm{l}$, p.a. (Merck 9057);

Acetone p.a. (Merck 14);

Ammonia, 25\% (minimum), p.a. (Merck 5432);

2,6-Dimethylpyridine (lutidine), $98 \%$ (Roth, Fluka, Koch-

Light): Due to its extreme sensitivity to oxidation, dimethyl-

pyridine must be redistilled before each chromatography series.

\section{Equipment}

Micropipets, $10 \mu$ l, (Camag);

Round glass development chambers $(200 \times 100 \mathrm{~mm})$ from

Riedcl-de Häen (can be obtained from Garquoin \& Reuter,

645 Hanau); 50 - $\mathrm{ml}$ beakers (tall)

15-ml centrifuge tubes (Schott No. 2060111);

Spectrophotometer.

\section{Authentic substances for comparison}

Coproporphyrin I and III were obtained as the methyl esters from Koch-Light and Calbiochem. They were also isolated from microbial cultures grown in the presence of $\delta$-amino-levulinic acid (12).

\section{Methods}

\section{Hy'droly'sis of the coproporphyrin methyl esters}

A small amount of coproporphyrin methyl ester (20-700 ng) is dissolved in a few drops of chloroform and applied to an acid-resistant silica gel thin-layer plate with a Camag micropipet. After the chloroform has evaporated, the tetramethyl ester is hydrolyzed by dropping $25 \% \mathrm{HCl}$ onto it with a Camag micropipet. The optimum volume of $\mathrm{HCl}$ for the hydrolysis is $0.3 \mathrm{ml}$ for $20-100 \mathrm{ng}$ coproporphyrin methyl ester. For more than $100 \mathrm{ng}$ substance, $0.3 \mathrm{ml} \mathrm{HCl}$ per $100 \mathrm{ng}$ coproporphyrin methyl ester should be used. After each application of the hydrochloric acid, the silica gel layer must dry in the air. The total hydrolysis time should always be at least $3 \mathrm{~h}$ at room temperature.

\section{Chromatography}

\section{Prerun}

To transform the round applied spot into a straight, sharp starting line, the plate is run twice in a round chromatography chamber in the solvent system $1 \mathrm{~mol} / \mathrm{l}$ hydrochloric acid + ace tone (volumes $20 \mathrm{ml}$ and $50 \mathrm{ml}$ ). Afterwards the plate is dried under a hair dryer.

\section{Separation of the isomers}

2,6-dimethyl pyridine $(20 \mathrm{ml})$ and distilled water $(6 \mathrm{ml})$ are carefully mixed in a Riedel chamber. Then a $50-\mathrm{ml}$ beaker containing $10 \mathrm{ml} 25 \%$ ammonia solution is placed in the chamber. The optimum time for saturation is $15 \mathrm{~min}$. Then the completely dry silica gel plate can be placed in the solvent. One must be careful to place the plate with its back (the glass side) toward the ammonia beaker.

\section{Elution of the free coproporphyrin acids I and III}

The coproporphyrin isomers I and III are marked on the chromatogram under long-wave UV light $(366 \mathrm{~nm})$. Coproporphyrin III is the faster migrating substance (Fig. 1 and 2).

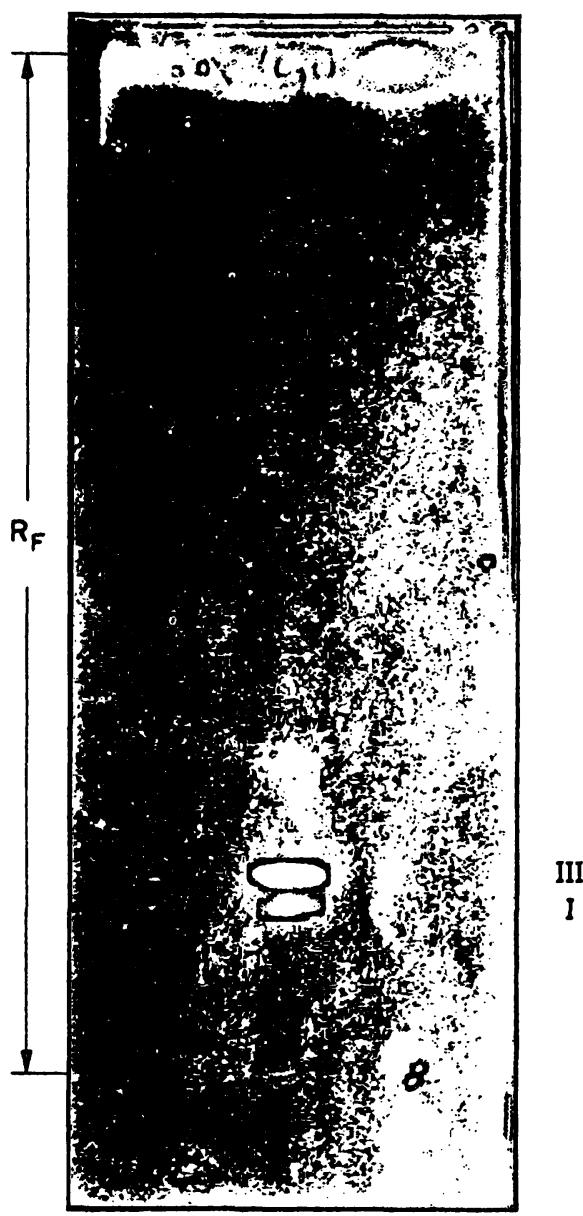

Fig. 1. Silica gel thin-layer chromatogram of the coproporphyrin isomers I and III from the urine of a patient with acute intermittent porphyria.

The separation of the isomers was done in the solvent system 2,6-dimethylpyridine/water (volumes $20 \mathrm{ml}+6 \mathrm{ml}$ ) in an ammonia atmosphere.

The fluorescent silica gel regions are scraped off the glass with a scalpel, transferred to a centrifuge tube, and extracted with $1.00 \mathrm{ml}$ of $1 \mathrm{~mol} / \mathrm{l}$ hydrochloric acid. The coproporphyrins are immediately eluted by briefly shaking the tube.

\section{Spectrophotometric measurement}

After centrifugation of the samples $(1200 \mathrm{~g}, 5 \mathrm{~min})$, the absorption of the eluate is measured in a spectrophotometer against $1 \mathrm{~mol} / 1 \mathrm{hydrochloric}$ acid between 650 and $380 \mathrm{~nm}$ (Fig. 3). (The silica gel itself has no absorption.) The absorption maximum of the Soret band of the coproporphyrins I and III is at $401.5(401-402) \mathrm{nm}$. The secondary peaks are at 590 (I) and 548 (II) $\mathrm{nm}$.

Calculation of the concentrations of the coproporphyrin isomers The corrected extinction $E_{\text {corr }}=2 \times E_{\max }-\left(E_{380}+E_{430}\right)$ is calculated from the general correction formula for the Soret maximum of the free porphyrin acids (14). The percentage of coproporphyrin I and III is determined from the sum of the corrected extinctions. The quantity of the isomers can also be calculated from the amount of the total coproporphyrin methyl ester, which was determined before the beginning of the isomer analysis $(11,12)$.

\section{Fluorimetric measurement}

As an alternative to the spectrophotometric analysis, the coproporphyrin isomers can also be determined in situ, that is, directly in the thin-layer chromatogram, by fluorimetry (15). 


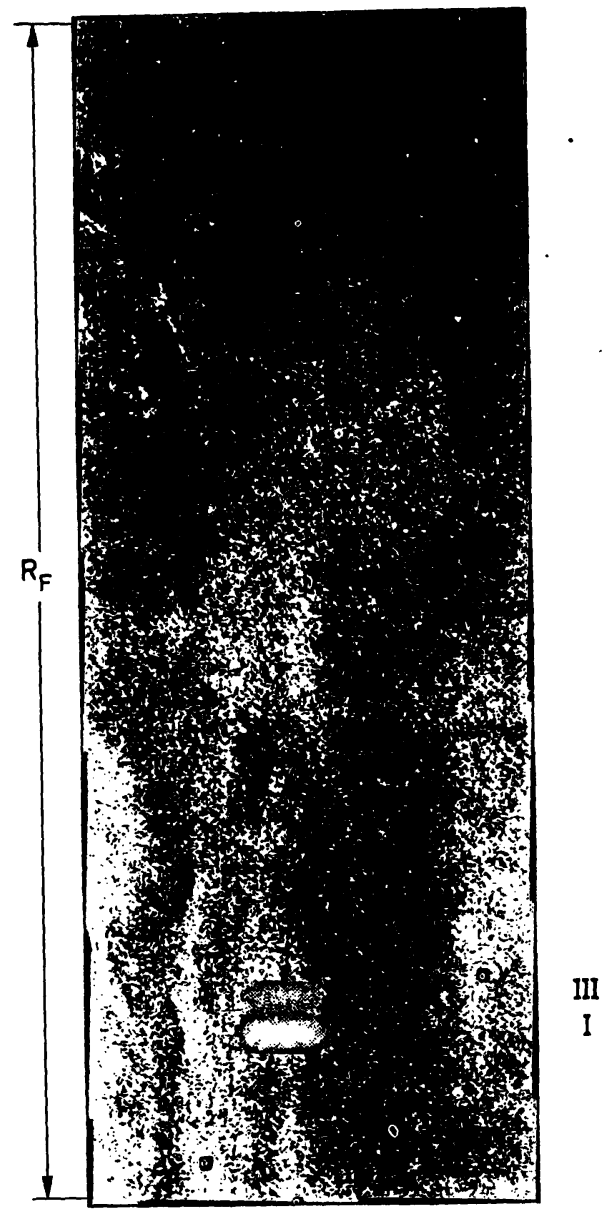

Fig. 2. Silica gel thin-layer chromatogram of the coproporphyrin isomers I and III from the urine of a patient with porphyria cutanea tarda. For the solvent system, see the legend to Fig. 1.

Technical sources of error

1. The hydrolysis time can be lengthened at will, but it must not be shortened. Too little hydrolysis reagent or too short an hydrolysis time, like incomplete drying of the silica gel layer after each drop of hydrochloric acid, will cause a separation of the coproporphyrins into as many as eight different bands, which have not yet been identified. In any case they are coproporphyrins: free isomeric acids, and probably partially esterified coproporphyrins. For the same reason, the working temperature should not exceed $25^{\circ} \mathrm{C}$, so that the hydrolysis time is not shortened.

2. The thin-layer plate is completely dry when it looks homogeneous in transmitted light. If the plate is not completely dried after the prerun, the separation of the isomers, which probably depends on the formation of ammonium chloride, is hampered.

3. 2,6-Dimethylpyridine oxidizes very easily. For perfect chromatography, the dimethylpyridine must be distilled before use and stored in light-protected bottles under nitrogen gas.

4. If the ammonia solution is spilled from the beaker into the 2.6-dimethylpyridine/water system, the isomers cannot be separated.

5. Fresh solvents must always be used for a good separation.

6. If the separation is not optimal, rechromatography in the same solvent system with about $30 \mathrm{ml} 25 \%$ ammonia solution (see above) is recommended.

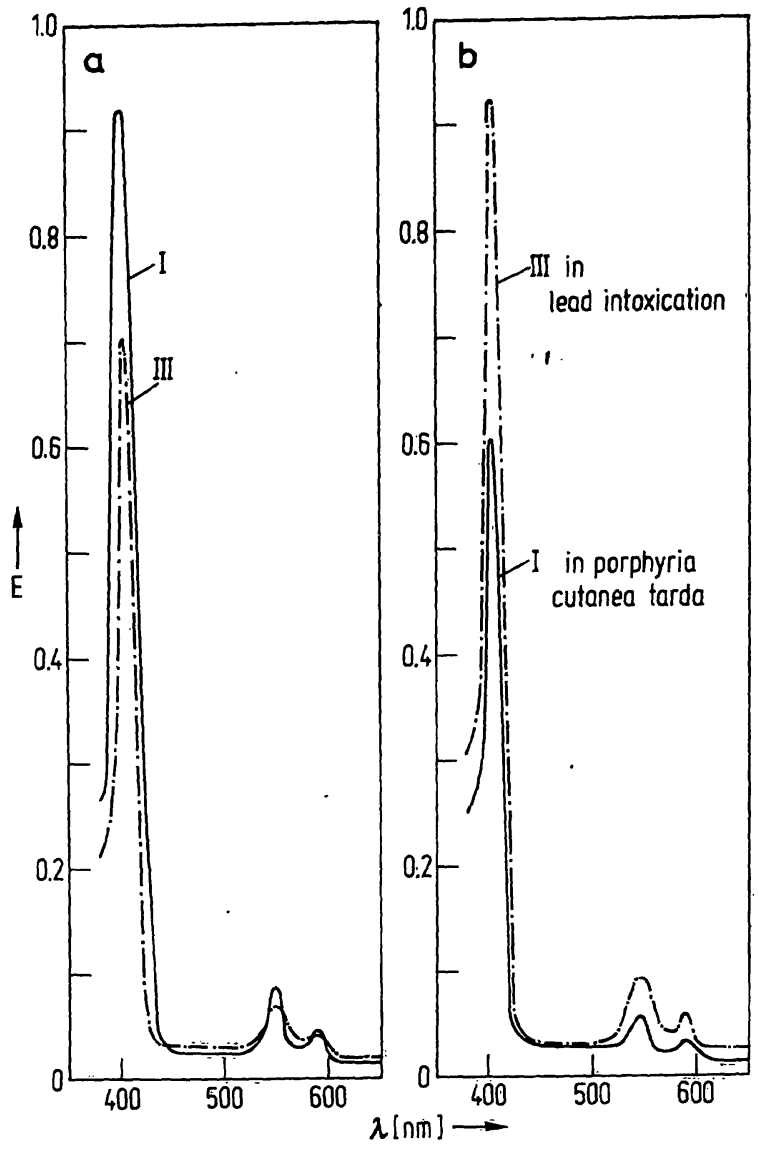

Fig. 3. Dicationic spectra of the free coproporphyrinic acids: Isomer I (-) and isomer III (.-.-) as test substances (A) compared to coproporphyrin isomer I $(-)$ from porphyria cutanea tarda and coproporphyrin isomer III (.-.-) from lead poisoning.

Results

The results obtained in the analysis of the coproporphyrin isomers in urine by thin-layer chromatography on acid-resistant, pre-coated plates with the solvent system 2,6-dimethylpyridine/water are given in Table 3.

The specificity is primarily based on the thin-layer chromatographic isolation and spectrophotometric analysis of the coproporphyrin methyl ester (12). This coproporphyrin methyl ester is subjected to hydrolysis and to chromatography of the biochemically and diagnostically relevant isomers I and III. The specificity is secondarily based on the separation procedure, which was tested with the pure compounds, and the spectrophotometric analysis of the free coproporphyrin acids I and III, whose spectra, unlike those of the methyl esters, have a dicationic form (Fig. 3).

The accuracy of the method was tested by recovery experiments after hydrolysis and chromatography. There was no significant loss of one isomer compared to the other in the course of the analysis. Both isomers were $89 \%$ recovered $(n=12, C V=6 \%)$. 
Tab. 3. Coproporphyrin isomers I and III in urine. Results from analytical thin-layer chromatography.

Number of Fraction of subjects copropor-

(n) pliyrin III

$(\bar{x} \pm s$ in $\%)$

1. Controls

2. Acute intermittent porphyria

$7 \% .5 \pm 6.4$

3. Chronic hepatic porphyria

Type A

Type B

Type C

4. Porphyria cutanea tarda

15

6

$87.3 \pm 9.6$

$81.0 \pm 10.7$

$77.2 \pm 8.3$

$68.0 \pm 9.1$

$67.1 \pm 11.7$

17.4

$49.2 \pm 8.7$

$95.0 \pm 4.6$

6. Ery thropoietic protoporphyria

7. Lead poisoning

$93.5 \pm 4.1$

8. Oral loading with 8 -aminolevulinic 4 acid $(12 \mathrm{mg} / \mathrm{kg}$ body weight $)$ in control subjects

9. Oral loading with $\delta$-aminolevulinic 4 acid $(12 \mathrm{mg} / \mathrm{kg}$ body weight) in patients with acute intermittent porphyria

\section{Discussion}

The biosynthetic pathway of porphyrins leads to protoporphyrin and then to heme, but only with the isomers of the III series. The pathway of the I isomers ends at the level of the coproporphyrinogens or coproporphyrins. A completely defective enzyme in the anabolic sequence of the porphyrin III series would be fatal, since it would be coupled with a complete inhibition of the biosynthesis of the porphyrin proteins. Inferences as to the function of the uroporphyrinogen-synthesizing enzyme system, which is composed of the uroporphyrinogen I synthase and uroporphyrinogen cosynthase (uroporphyrinogen isomerase), may thus be drawn from the analysis of the coproporphyrin isomers. This enzyme system is defective in porphyria erythropoietica congenita (Morbus Günther), acute intermittent porphyria and porphyria cutanea tarda. Furthermore, if the decarboxylation of higher carboxylated porphyrins to coproporphyrin is followed by isomer analysis, it is possible to obtain insight into the decarboxylase system, which has not yet been closely studied, with respect to the enzymatic activities of the I and III isomer series.

The method described here has the important advantage over previously published techniques in that it is an adaptation of quantitative analysis of coproporphyrin isomers pre-coated thin-layer plates, which can be evaluated both spectrophotometrically and fluorimetrically. Furthermore, the technique of hydrolyzing the methyl esters directly on the plate makes it possible to analyze nanogram quantities, prevents loss of the substances, and allows the chromatography to follow directly upon hydrolysis.

It was thus possible to carry out routine examinations with an acceptable expenditure of labor. Since freshly distilled dimethylpyridine must always be used, it has been found advantageous in practice to chromatograph about 20 samples simultaneously.

The results obtained (Tab. 3) agree with the most recent literature data (compare Tables 1 and 2).

It must be emphasized that the above isomer analysis depends on the determination of an absolute value for the coproporphyrins. That is, the coproporphyrins present in a biological sample are separated as the methyl esters, isolated and their amount calculated (12), so that the isomer analysis serves only to determine the relative proportions. These can then be converted to absolute amounts on the basis of the known value for the total coproporphyrins. For this reason, we did not determine the millimolar extinction coefficients for the coproporphyrins I and III; if a direct quantitative or concentration determination is undertaken, based on the isomer analysis, the reader is referred to the extinction coefficients of Falk (14). 
However, if the total porphyrin content is known, only the isomeric distribution, and not the total amounts of isomers, is of further biochemical or diagnostic interest.

In the following, a few methodological considerations which influence the quality of the separation will be discussed.

A $25 \%$ hydrochloric acid solution is necessary to hydrolyze the coproporphyrin methyl esters in the silica gel. Experiments with less concentrated hydrochloric acid, such as 3,1 or $0.5 \mathrm{~mol} / 1 \mathrm{HCl}$, produced only partial hydrolysis, even when larger volumes of hydrochloric acid were used. It is also impossible to reduce the hydrolysis time. The quality of the separation depends both on a complete hydrolysis of the coproporphyrin methyl esters and on the exact composition of the solvent system. If more than $7 \mathrm{ml}$ distilled water is used, and the substances are allowed to migrate over longer distances, the separation of the isomers is impaired.

\section{References}

1. Jensen, J. (1963). J. Chromatogr. 10, 236-238.

2. Eriksen, L. (1958), Scand. J. Clin. Lab. Invest. 10, 319-322.

3. Aziz, M. A., Schwartz, S. \& Watson, C. J. (1964), J. Lab. Clin. Med. 63;583-595; 596-604.

4. Swecney, G. D. \& Eales, L. (1964), Scand. J. Clin. Lab. Invest. $16,250-251$.

S. Koskelo, P. \& Toivonen, I. (1966), Scand. J. Clin. Lab. Invest. 18, 543-549.

6. Chu, T. C. \& Chu, E. J.-H. (1967), J. Chromatogr. 28, $475-478$.

7. Dowdlc, E., Goldswain, P., Spong, N. \& Eales, L. (1970), Clin. Sci. 39, 147-158.

8. Moore, W. E., Stephenson, B. D., Anderson, A. S. \& Schwartz, S. (1970), Proc. Soc. Exp. Biol. Med. 134, 926-929.

9. Ben-Ezzer, J., Rimington, C., Shani, M., Scligsoln, U., Sheba, Ch. \& Szcinberg, A. (1971), Clin. Sci. 40, 17-30.

10. Kaplowitz, N., Javitt, N. \& Kappas, A. (1972), J. Clin. Invest. 51, 2895-2899.

11. Doss, M. \& Mannheim, W. (1967), this J. 5, 260-264.

12. Doss, M. (1970), this J. 8, 197-207.

13. Doss, M., Look, D., Henning, H., Lüders, C. J., Dölle, W. \& Strohmeyer, G. (1971), this J. 9, 471-477.
If less than $5 \mathrm{ml}$ water is used, the coproporphyrins do not leave the starting line, on account of the low polarity of the solvent. The use of more concentrated ammonia, i. e. $33 \%$ solution, produces a more rapid separation of the isomers, but the bands are wavy, so that rechromatography is necessary in most cases. For the same reason, the thin-layer plates must be placed in the chromatography tank with their backs to the ammonia vessel.

Activation of the pre-coated thin-layer plates before and after the application of the substances had no effect on the quality of the separation.

\section{Acknowledgement}

This research was supported by the Deutsche Forschungsgemeinschaft.

14. Falk, J. E. (1964), Porphyrins and Metalloporphyrins, Elsevier (Amsterdam), p. 171-171.

15. Doss, M., Ulshöfer, B. \& Philipp-Dormston, W. K. (1971), J. Chromatogr. 63, 113-120.

16. Doss, M. (1974), in: Regulation of Porphyrin and Heme Biosynthesis, (M. Doss, Ed.), pp. 343-353, S. Karger Basel.

17. Koskelo, P., Toivonen, I. \& Adlercreutz, H. (1967), Clin. Chem. 13, 1006-1009.

18. Koskelo, P. \& Toivonen, I. (1968), Acta Obstet. Gynec. Scand. 47, 292-299.

19. Chu, T. C. \& Chu, E. J.-H. (1967), Clin. Chem. 13, 371-387.

20. Nacht, S., San Martin de Viale, L. C. \& Grinstein, M. (1970), Clin. Chim. Acta 27, 445-452.

21. Watson, C. J. (1936), J. Clin. Invest. 15, 327-334.

22. Vigliani, E. \& Waldenström, J. (1937), Deut. Arch. Klin. Med. 180, 182-192.

23. Vigliani, E. C. \& Libowitsky, H. (1937), Klin. Wochenschr. $16,1243-1245$.

24. Romeo, G. \& Levin, E. Y. (1969), Proc. Nat. Acad. Sci. USA $63,856-863$.

Prof. Dr. Manfred Doss

Abteilung für Klinische Biochemie am

Hygiene-Institut der Universität

D-3550 Marburg a. d. Lahn

Pilgrimstein 2, Tel. 06421/28 4367

Bundesrepublik Deutschland 